\title{
First Estimation of Reference Intervals for Thyroid-Stimulating Hormone and Thyroid Hormones in Slovenian Population
}

\author{
Adrijana Oblak, ${ }^{1}$ Ajda Biček, ${ }^{1}$ Edvard Pirnat, ${ }^{1}$ Katja Zaletel ${ }^{1,2}$ \\ and Simona Gaberšček ${ }^{1,2, *}$ \\ ${ }^{1}$ Department of Nuclear Medicine, University Medical Centre Ljubljana, Zaloška 7, 1525 Ljubljana, Slovenia \\ ${ }^{2}$ Faculty of Medicine, University of Ljubljana, Vrazov trg 2, 1000 Ljubljana, Slovenia \\ * Corresponding author: E-mail: simona.gaberscek@kclj.si \\ telephone: +386152235 51, fax: +38615222237
}

Received: 02-17-2020

\begin{abstract}
For thyroid function estimation and clinical decision making, use of appropriate reference intervals for thyroid-stimulating hormone (TSH), free thyroxine $\left(\mathrm{fT}_{4}\right)$ and free triiodothyronine $\left(\mathrm{fT}_{3}\right)$ is crucial. For each laboratory, establishment of own reference intervals is advised. For the first Slovenian estimation of reference intervals for thyroid hormones a large group of 1722 healthy individuals without thyroid disease was established retrospectively. Hormone analyses were performed on automated analyser Advia Centaur XP Immunoassay System (Siemens Healthineers), which reference intervals for $\mathrm{TSH}_{1} \mathrm{fT}_{4}$ and $\mathrm{fT}_{3}$ were $0.55-4.78 \mathrm{mIU} / \mathrm{L}, 11.5-22.7 \mathrm{pmol} / \mathrm{L}$, and 3.5-6.5 pmol/L, respectively. Statistical analysis followed non-parametric percentile method. Our laboratory reference intervals for $\mathrm{TSH}, \mathrm{fT}_{4}$ and $\mathrm{fT}_{3}$ are mostly narrower than intervals given by manufacturer. Median value, lower and upper limit for $\mathrm{TSH}_{\text {, }} \mathrm{fT}_{4}$ and $\mathrm{fT}_{3}$ were 1.98 (0.59-4.23) $\mathrm{mIU} / \mathrm{L}, 14.5$ (11.3-18.8) pmol/L and 4.82 (3.79-6.05) pmol/L, respectively. Most likely, an inclusion of a high number of healthy individuals without thyroid disease was a reason for such results.
\end{abstract}

Keywords: reference intervals; thyroid-stimulating hormone; thyroid hormones; immunoassays; interferences

\section{Introduction}

Biochemical parameters obtained from blood sampling are an important part of clinical decision-making. However, a path from ordering a test by a clinician to the value of an analyte in blood is long and is facing several important and critical steps which can influence the end result and, consequently, a clinical decision. Important part of this process is preanalytics which combines different aspects from biological variability to sample collection and sample handling prior to analysis. ${ }^{1}$ Preanalytics is a source of majority of errors and should therefore be carefully executed. ${ }^{2}$ The primary goal of every medical examination is to cause no harm to a patient. Incorrect test results expose a patient to diagnostic errors and an institution to unnecessary additional costs. ${ }^{3}$ As a part of a good laboratory practice our laboratory follows Clinical Laboratory Standard Institute (CLSI) guidelines which propose each laboratory should determine its own reference intervals on its own population in their own laboratory environment. ${ }^{4}$ When laboratory prepares reference intervals for any kind of hormones in a population, it is facing several problems. Excretion of hormones differs on daily, weekly, monthly, seasonally basis, and also depends on sex, age, drugs, and different physiological states like pregnancy or puberty. Inclusion of a large number of individuals in the establishment of reference intervals may overcome those problems. It is also important to set the time of blood withdrawal to prevent incorrect interpretation of results, especially for hormones following circadian rhythm like thyroid-stimulating hormone (TSH). ${ }^{5}$ Studies have shown that the time of sample collection has an impact on serum TSH value and should therefore be standardized to minimize the impact of false TSH values on clinical decisions especially in subclinical hypothyroidism, which is defined as elevated TSH, and normal free thyroxine $\left(\mathrm{fT}_{4}\right)$ and free triiodothyronine $\left(\mathrm{fT}_{3}\right)$ values. ${ }^{6}$ This fact was confirmed by our study from 2016 which showed that $23 \%$ of patients sent to our department from periphery laboratories because of mildly elevated TSH (up to $10 \mathrm{mIU} / \mathrm{L}$ ) had normal thyroid gland, and only $22 \%$ really had elevated TSH after the complete thyroid examination. ${ }^{7}$ Other $55 \%$ had Hashimoto's thyroiditis in euthyroid phase. A possible 
explanation for such differences could be too early blood collection in the periphery laboratories. Generally, preferable time of blood collection for various tests is in fasting state from 7 a.m. to 9 a.m. ${ }^{8}$ If within the same timeframe also a blood sample for thyroid function assessment is taken, a falsely elevated TSH level could be measured. ${ }^{9}$ Increased TSH level may be associated with unnecessary treatment or with unnecessary referral to thyroid specialist that prolongs waiting list of patients for examination.

Reference intervals for each assay are given by manufacturer in the Instructions for use (IFU). Given data, however, usually lack information regarding health of reference population, median values and the time of collection of samples. The data that are obtained on samples chosen by manufacturer are from apparently healthy adult individuals. However, no data on their actual health or thyroid status is available.

In several studies, reference values were established in various populations. In most studies, the exclusion criteria were not such that individuals with thyroid disorders could be excluded or the values were obtained from databases only. Thyroid diseases were mostly excluded by patient's history, or by laboratory tests only and not by complete clinical examination. ${ }^{10,11,12}$

Therefore, the aim of our work was to establish laboratory-own reference intervals for $\mathrm{TSH}, \mathrm{fT}_{4}$ and $\mathrm{fT}_{3}$ on a method we are using in our laboratory considering the time frame in which TSH has the lowest values according to circadian rhythm - from 9 a.m. to 3 p.m. in a large group of clinically examined individuals without thyroid disease.

\section{Experimental}

We reviewed medical records of all adult patients who were examined by thyroid specialist for the first time in their life between January 1, 2011, and December 31, 2014, at the Department of Nuclear Medicine, University Medical Centre Ljubljana, Slovenia. In all patients, a routine clinical examination including thyroid ultrasound was performed followed by the measurement of serum concentration of $\mathrm{TSH}, \mathrm{fT}_{4}, \mathrm{fT}_{3}$, thyroglobulin antibodies $(\mathrm{Tg}-\mathrm{Ab})$, and thyroid peroxidase antibodies (TPO-Ab). Reference intervals given by manufacturer at the time of analysis were for TSH 0.55-4.78 mIU/L, $\mathrm{fT}_{4}$ 11.5-22.7 $\mathrm{pmol} / \mathrm{L}, \mathrm{fT}_{3} 3.5-6.5 \mathrm{pmol} / \mathrm{L}$, and for $\mathrm{Tg}-\mathrm{Ab}$ and $\mathrm{TPO}-\mathrm{Ab}$, up to $60 \mathrm{kU} / \mathrm{L}$. We only included data of patients with a normal thyroid gland, with no associated diseases and without amiodarone or other drugs influencing the level of $\mathrm{TSH}, \mathrm{fT}_{4}$ and $\mathrm{fT}_{3}$ such as glucocorticoids or psychotropic medication. Data from pregnant individuals were not included in the study. We found 2073 reference individuals from 15 to 93 years of age who met these criteria. Following $\mathrm{CLSI}^{3}$ guidelines only those from 18 to 65 years of age were included into reference group, which made a group of 1722 reference individuals.

\section{1. Sample Preparation}

Venous blood was collected following standardized protocol of venous blood sampling used at the department. ${ }^{13}$ Blood was taken from 9 a.m. to 3 p.m. into serum collective tubes (BD Vacutainer blood collection tubes) by trained nurses. Transportation was made across the hall since laboratory is a part of the department. Blood was coagulating for $30 \mathrm{~min}$ and was centrifuged afterwards at 4 ${ }^{\circ} \mathrm{C}$ for $10 \mathrm{~min}$ at $3000 \mathrm{rpm}$. Measurements of all parameters were performed on the day of collection using serum from primary tube.

\section{2. Analysis}

All biochemical analyses were performed on automated analyser Advia Centaur XP Immunoassay System (Siemens Medical Solutions Diagnostics, Dublin, Ireland) using chemiluminescent principle. All analyses on Advia Centaur are traceable to standardization. The TSH3-Ultra assay standardization is traceable to the World Health Organization (WHO) $3^{\text {rd }}$ International Standard for human TSH (IRP 81/565), which is the last generation of tests available on the market. ${ }^{14} \mathrm{The}_{\mathrm{fT}}$ and $\mathrm{fT}_{3}$ assays are traceable to an internal standard manufactured using U.S.P. (United States Pharmacopeia). ${ }^{15}$ The Tg-Ab standardization is traceable to the WHO Reference Preparation MRC 65/93 and the TPO-Ab standardization is traceable to the WHO Reference Preparation MRC 66/387. ${ }^{16}$ Performance characteristics for all assays are as follows. TSH limit of detection is $0.008 \mathrm{mIU} / \mathrm{L}$, linearity of the assay is in the range from 0.008 to $150.0 \mathrm{mIU} / \mathrm{L}$ with the recovery range from 96.3 to $105.0 \%$. TSH intra-assay and inter-assay coefficients of variation ranged from $2.4 \%$ to $4.9 \%$ and from $1.5 \%$ to $4.4 \%$, respectively. Limits of detection for $\mathrm{fT}_{4}$ and $\mathrm{fT}_{3}$ are $1.3 \mathrm{pmol} / \mathrm{L}$ and $0.3 \mathrm{pmol} / \mathrm{L}$, respectively, linearities of the assays are in the range from 1.3 to 155.0 $\mathrm{pmol} / \mathrm{L}$, and 0.3 to $30.8 \mathrm{pmol} / \mathrm{L}$, respectively. Intra-assay and inter-assay coefficient of variations for free thyroid hormones, $\mathrm{fT}_{4}$ and $\mathrm{fT}_{3}$, ranged from $2.22 \%$ to $4.69 \%$ and from $1.58 \%$ to $4.59 \%$ for $\mathrm{fT}_{4}$ and from $2.35 \%$ to $3.08 \%$ and from $2.76 \%$ to $4.05 \%$ for $\mathrm{fT}_{3}$. Limits of detection for TPO$\mathrm{Ab}$ and $\mathrm{Tg}-\mathrm{Ab}$ are $28 \mathrm{kU} / \mathrm{L}$ and $15 \mathrm{kU} / \mathrm{L}$, respectively, while linearities of the assays are in the range from 28 to $1300 \mathrm{kU} / \mathrm{L}$ and from 15 to $500 \mathrm{kU} / \mathrm{L}$, respectively. TPO$\mathrm{Ab}$ and $\mathrm{Tg}-\mathrm{Ab}$ intra-assay and inter-assay coefficient of variations ranged from $1.3 \%$ to $6.8 \%$ and from $2.8 \%$ to $3.4 \%$ for $\mathrm{TPO}-\mathrm{Ab}$ and from $2.9 \%$ to $5.5 \%$ and from $1.8 \%$ to $2.0 \%$ for $\mathrm{Tg}-\mathrm{Ab}$, respectively. Cross-reactivity of TSH assay was shown non-detectable for human chorionic gonadotropin (hCG), follicle-stimulating hormone (FSH), and luteinizing hormone (LH) tested at 200.000 $\mathrm{mIU} / \mathrm{L}, 1500 \mathrm{mIU} / \mathrm{L}$, and $600 \mathrm{mIU} / \mathrm{L}$, respectively. Cross-reactivity for $\mathrm{fT}_{4}$ and $\mathrm{fT}_{3}$ assays was below $1.0 \%$ for diiodotyrosine, monoiodotyrosine, and reverse $\mathrm{T}_{3}$. Quality controls $(\mathrm{QC})$ for $\mathrm{TSH}, \mathrm{fT}_{4}$, and $\mathrm{fT}_{3}$ were performed using independent control material, Liquicheck Immuno- 
assay Plus Control, Trilevel \#360 (Bio-Rad Laboratories, Inc.). As for $\mathrm{Tg}-\mathrm{Ab}$ and $\mathrm{TPO}-\mathrm{Ab}$ control material Advia Centaur Systems QC anti-TG and anti-TPO 1,2 (Siemens Healthcare Diagnostics, Inc.) based on LOT of reagent were used, low and high level.

\section{3. Estimation of Reference Intervals}

Reference values for $\mathrm{TSH}, \mathrm{fT}_{4}$, and $\mathrm{fT}_{3}$ from data of reference individuals were estimated using statistical program MedCalc Statistical Software version 14.8.1 (MedCalc Software bvba, Ostend, Belgium, 2014). Reference intervals were determined by non-parametric percentile method following CLSI EP28-A3 with 95\% reference interval, double sided. Outliers were analysed using Reed et al. and none were detected. ${ }^{17}$ Results are presented as lower and upper limit of reference values for each parameter for all individuals and separately for men and women.

\section{4. Ethical Approval}

Study was approved by the Republic of Slovenia National Medical Ethics Committee (number 47/08/14, October 24, 2014).

\section{Results and Discussion}

Into the reference group, 398 men and 1324 women were included with the average age of 43 years for men and 38 years for women, respectively. The data are not symmetrically distributed $(\mathrm{P}<0.0001)$, therefore, a non-parametric percentile method was used. The obtained intervals from 2.5th to 97.5th percentile are presented in Table 1 including $90 \%$ coefficient interval and histograms of the distribution of results are followed below in Figure 1. For comparison, manufacturer's intervals are also given.

Table 1. Reference intervals for serum concentration of $\mathrm{TSH}, \mathrm{fT}_{4}$ and $\mathrm{fT}_{3}$ obtained from 1722 reference individuals, given also separately for men (398) and women (1324). Comparison of laboratory-own and manufacturer's reference intervals.

\begin{tabular}{lccc}
\hline Parameter & TSH $(\mathbf{m I U} / \mathrm{L})$ & $\mathbf{f T}_{\mathbf{4}}(\mathbf{p m o l} / \mathrm{L})$ & $\mathbf{f T}_{\mathbf{3}}(\mathbf{p m o l} / \mathrm{L})$ \\
\hline Lower limit $^{\mathrm{a}}$ & $\mathbf{0 . 5 9}$ & $\mathbf{1 1 . 3}$ & $\mathbf{3 . 7 9}$ \\
CI 90\% $^{\mathrm{a}}$ & $0.56-0.62$ & $11.1-11.4$ & $3.74-3.85$ \\
& & & \\
Upper limit $^{\mathrm{a}}$ & $\mathbf{4 . 2 3}$ & $\mathbf{1 8 . 8}$ & $\mathbf{6 . 0 5}$ \\
CI 90\% $^{\mathrm{a}}$ & $4.16-4.44$ & $18.4-19.0$ & $5.91-6.16$ \\
Men $^{\mathrm{a}}$ & $0.59-4.45$ & $11.3-19.4$ & $3.83-6.30$ \\
Women $^{\mathrm{a}}$ & $0.58-4.18$ & $11.3-18.5$ & $3.78-5.90$ \\
Advia Centaur XP $^{\mathrm{b}}$ & $0.55-4.78$ & $11.5-22.7$ & $3.5-6.5$ \\
\hline
\end{tabular}

\footnotetext{
${ }^{a}$ laboratory-own data; bmanufacturer's data TSH, thyroid-stimulating hormone; $\mathrm{fT}_{4}$, free thyroxine; $\mathrm{fT}_{3}$, free triiodothyronine; $\mathrm{CI}$, confidence interval
}
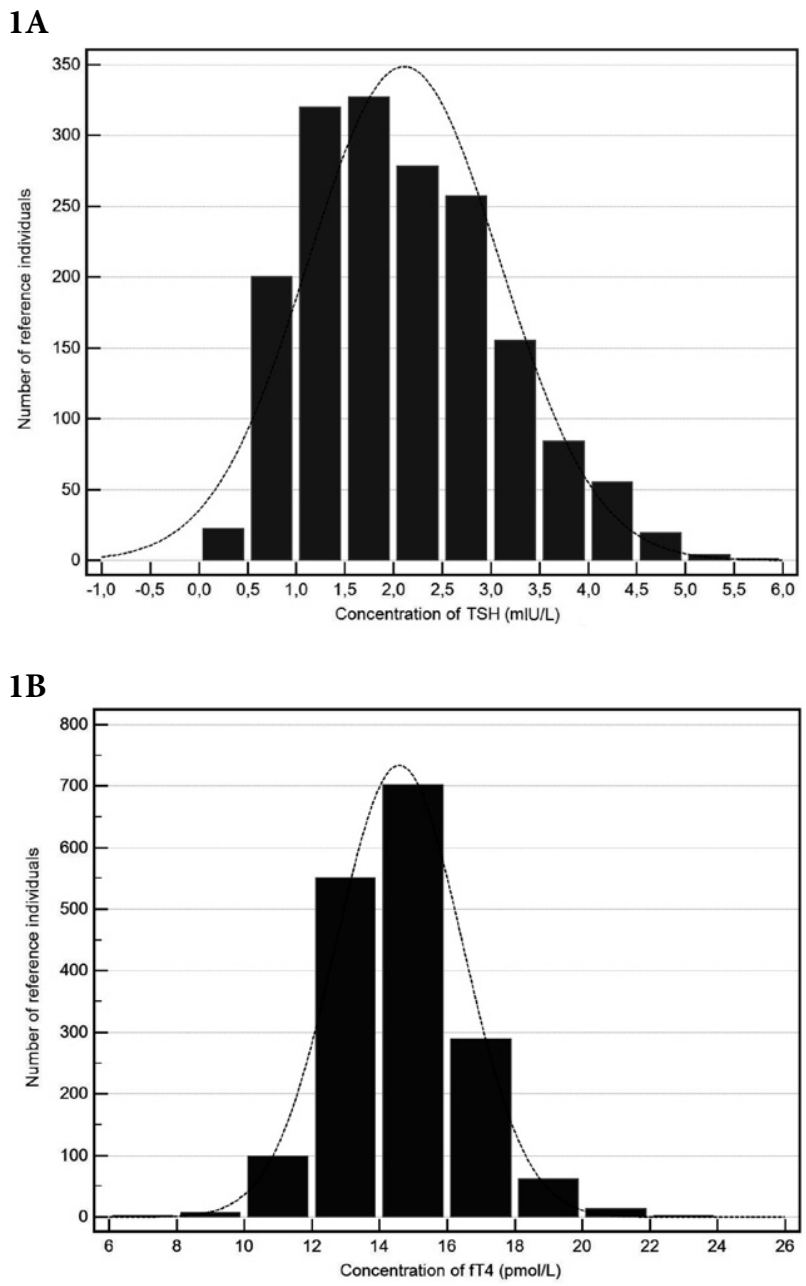

$1 \mathrm{C}$

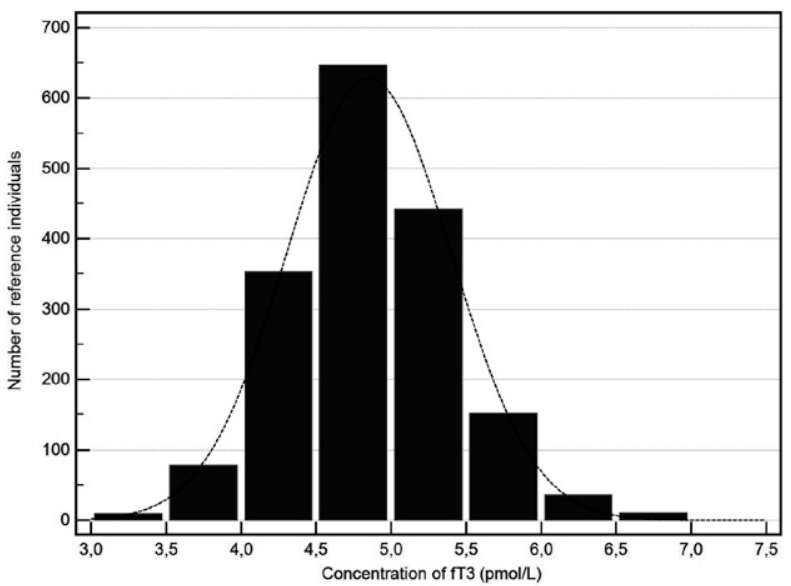

Figure 1. Histograms showing distribution of reference values in a population of 1722 reference individuals. 1A: TSH distribution of reference values with Coefficient of Skewness $0.5308(\mathrm{P}<0.0001)$ and Coefficient of Kurtosis -0.2141 ( $\mathrm{P}=0.0469)$; $1 \mathrm{~B}: \mathrm{fT}_{4}$ distribution of reference values with Coefficient of Skewness $0.4014(\mathrm{P}<$ $0.0001)$ and Coefficient of Kurtosis $0.7660(\mathrm{P}<0.0001) ; 1 \mathrm{C}: \mathrm{fT}_{3}$ distribution of reference values with Coefficient of Skewness 0.3044 (P $<0.0001)$ and Coefficient of Kurtosis $0.5839(\mathrm{P}=0.0001)$. 
We did not observe significant changes in reference ranges between men and women.

Distribution of reference values is not normal which is confirmed with Coefficients of Skewness and Kurtosis and with D'Agostino-Pearson test.

Establishment of laboratory-own reference intervals and their use in routine clinical practice should be performed cautiously. All factors influencing these values should be taken into account - preanalytical as well as analytical. Not only they will prevent us from an impact they would have to the calculation of lower and/or upper limits of intervals but they will also help us with setting the time of the day blood samples should be taken and in which it is appropriate to use them. This is very important when measuring serum levels of various hormones due to present biological variations such as pulsatile secretion and/or circadian rhythm.

In general, measurement of various hormones is complex. First, differences between different immunoassays due to usage of different detecting antibodies exist. This is a consequence of the nature of the individual analyte and of the prepared antibodies. Thus, the comparison of values between different immunoassay methods can mislead a clinician. This holds true especially for the measurements of peptide and protein hormones which lack standardization and, therefore, equivalency between assays is not possible. Second, methods have detection limits. Third, endogenous and exogenous interferences may importantly influence immunoassays and final concentrations. ${ }^{18}$ Endogenous substances are usually well known since they arrive from properties of the specimen. Nowadays, reagents are tested against some obvious interferences like molecules showing similar structure to analyte although an impact of autoantibodies, binding proteins, heterophile antibodies, human anti-animal antibodies always exists and one should always keep this in mind while evaluating results. On the other hand exogenous interferences are usually not known or at least not known to the laboratory due to lack of patient's history and any prior testing of interferences. This includes drugs, which can influence the measurement of an analyte, and can lead to false positive or negative test results. An important problem is also different food supplements, which - with the expansion of usage - impact the detection of hormones. They are also very hard to detect. Some interferences have been discovered lately, like biotin, which shows an important impact on immunoassays, especially those which are using biotin streptavidin reaction. ${ }^{19,20,21}$ Furthermore, associated diseases may influence test results. Thus, during the diagnostic procedure, it is important to standardize as many procedures as possible to minimize known influences. Therefore, the collaboration between a clinician and a laboratory is absolutely necessary. An important part of collaboration is also a special proximity of the laboratory and clinical part which is an advantage at our department.

While preparing reference intervals it is very important to know what kind of intervals you wish to prepare - healthy or unhealthy adults, children, pregnant women. Considering that, inclusion and exclusion criteria should be selected cautiously. Individuals with known associated diseases or medications could influence the end results and should not be included into the reference group.

In most methods, the exact data of health status of reference individuals are not given by manufacturer. However, for TSH and thyroid hormones, it is very important that we know health and thyroid status of reference individuals. In our study, we have established reference values for TSH and free thyroid hormones, which is the first such study performed in Slovenian adult population. All individuals were clinically examined by thyroid specialists. Therefore, presented data are based on really healthy population. We did not find this size of clinically and biochemically proven healthy reference population in the available literature. All the preanalytical and analytical influences were limited. The use of third generation TSH assay enabled us to determine values with good precision and reproducibility. We did not find any statistical difference in reference intervals between men and women, therefore reference intervals for the whole population were implemented. The significant differences in reference ranges between men and women were observed in Chinese population. ${ }^{22}$ By contrast, in the study from Brasil, no gender-related differences in reference ranges were found. ${ }^{23}$ This indicates the differences between populations and the necessity for determination of population-based reference intervals.

Our study showed narrower reference intervals as those proposed by manufacturer with the exception of the slightly lower limit for $\mathrm{fT}_{4}$. Most likely, an inclusion of a high number of thyroid-healthy individuals only was a reason for such results. Narrower reference intervals for $\mathrm{TSH}$ and $\mathrm{fT}_{4}$ were also found in the literature. ${ }^{24}$ Differences from reference intervals proposed by manufacturer were observed in all three analytes. The most pronounced change was observed in the upper level of $\mathrm{fT}_{4}$, which decreased from $22.7 \mathrm{pmol} / \mathrm{L}$ to $18.8 \mathrm{pmol} / \mathrm{L}$. This change enables detection of more patients with manifest hyperthyroidism (decreased level of TSH, increased level of $\mathrm{fT}_{4}$ or $\mathrm{fT}_{3}$ ). Generally, narrower reference intervals for $\mathrm{TSH}, \mathrm{fT}_{4}$ and $\mathrm{fT}_{3}$ help clinician not to overlook subclinical forms of thyroid disorders. Since these also have an important health impact, our results contribute to better management of thyroid patients.

Children and pregnant women were excluded from the study. For both populations, reference intervals should be prepared separately due to different physiology of thyroid hormone synthesis and secretion.

\section{Conclusions}

Laboratory-own reference intervals for $\mathrm{TSH}, \mathrm{fT}_{4}$ and $\mathrm{fT}_{3}$ on a method we are using in our laboratory consider- 
ing the time frame in which TSH has the lowest values according to circadian rhythm were established. These intervals are mostly narrower than intervals proposed by manufacturer and therefore improve management of thyroid patients by better detection of patients with subclinical thyroid disorders. Laboratories in the area which use the same methodology could take over the established reference intervals. If laboratory or manufacturer changes methodology, it is laboratory's responsibility to verify those changes and, if necessary, repeat the establishment of reference intervals.

\section{Acknowledgements}

The work has been supported by University Medical Center Ljubljana, Slovenia.

\section{Conflict of Interest}

The authors declare no conflict of interest.

\section{References}

1. S. Narayanan, Indian J. Clin. Biochem. 1996, 11, 7-11. DOI:10.1007/BF02868404

2. A. Atay, L. Demir, S. Cuhadar, G. Saglam, H. Unal, S. Aksun, B. Arslan, A. Ozkan, R Sutcu, Biochemia Medica. 2014, 24, 376-382. DOI:10.11613/BM.2014.040

3. M. L. Graber, N. Franklin, R. Gordon, Arch. Intern. Med. 2005, 165, 1493-1499. DOI:10.1001/archinte.165.13.1493

4. Clinical Laboratory Standard Institute. Defining, establishing, and verifying reference intervals in the clinical laboratory; Approved Guideline, 3rd edition. CLSI Document EP28-A3c. Wayne, PA, 2010 https://clsi.org/media/1421/ep28a3c_sample.pdf (assessed: February 16, 2020).

5. C. Lucke, R. Hehrmann, K. von Mayersbach, A. von zur Mühlen, Acta Endocrinol. (Copenh). 1977, 86, 81-88.

DOI:10.1530/acta.0.0860081

6. B. Mirjanic-Azaric, T. Stojakovic-Jelisavac, B. Vukovic, D. Stojanovic, M. Vujnic, S. Uletilovic, Clin. Biochem. 2015, 48, 1347-1349. DOI:10.1016/j.clinbiochem.2015.08.020

7. S. Gaberšček, L. Petek-Hojker, S. Hojker, Zdrav. Vestn. 2002, 71, 485-486.

8. A. M. Simundic, M. Cornes, K. Grankvist, G. Lippi, M. Nybo, Clin. Chim. Acta. 2014, 432, 33-37.

DOI:10.1016/j.cca.2013.11.008

9. J. Ehrenkranz, P. R. Bach, G. L. Snow, A. Schneider, J. L. Lee, S. Ilstrup, S. T. Bennett, S. Benvenga, Thyroid. 2015, 25, 954961. DOI:10.1089/thy.2014.0589

10. T. Vadiveloo, P. T. Donnan, M. J. Murhpy, G. O. Leese, J. Clin. Endocrinol. Metab. 2013, 98, 1147-1153.

DOI:10.1210/jc.2012-3191

11. J. H. Barth, A. Luvai, N. Jassam, W. Mbagaya, E. S. Kilpatrick, D. Narayanan, S. Spoors, Ann. Clin. Biochem. 2018, 55, 107112. DOI:10.1177/0004563217691549
12. S. Y. Park, H. I. Kim, H.-K. Oh, T. H. Kim, H. W. Jang, J. H. Chung, M.-H. Shin, S. W. Kim, PLoS. ONE. 2015, 13, e0190738.

13. M. Piskar. Priporočeni postopek za odvzem venske krvi. Slovenian association for clinical chemistry and laboratory medicine, 1st ed. Ljubljana, 1999. https://www.szkklm.si/si/vsebina/eflm-48/nova-eflm-priporocila-za-odvzem-venske-krvi (assessed: February 16, 2020)

14. Thyroid Stimulating Hormone, Human. WHO International Standard 81/565. https://www.nibsc.org/products/brm product_catalogue/detail_page.aspx?catid=81/565 (assessed: March 27, 2021).

15. United States Pharmacopeia. https://www.usp.org/ (assessed: March 27, 2021).

16. WHO International Biological Reference Preparation. https://www.who.int/bloodproducts/ref_materials/catalogue_miscellaneous.pdf (assessed: March 27, 2021).

17. A. H. Reed, R. J. Henry, W. B. Mason, Clin. Chem. 1971, 17, 275-284. DOI:10.1093/clinchem/17.4.275

18. J. Tate, G. Ward, Clin. Biochem. Rev. 2004, 25, 105-120.

19. A. Clerico, M. Plebani, Clin. Chem. Lab. Med. 2017, 55, 777779. DOI:10.1515/cclm-2017-0070

20. M. L. Piketty, M. Polak, I. Flechtner, L. Gonzales-Briceño, J. C. Souberbielle, Clin. Chem. Lab. Med. 2017, 55, 780-788. DOI:10.1515/cclm-2016-0606

21. C. Trambas, Z. Lu, T. Yen, K. Sikaris, Ann. Clin. Biochem. 2018, 55, 205-215. DOI:10.1177/0004563217701777

22. Z.-Z. Li, B.-Z. Yu, J.-L. Wang, Q. Yang, J. Ming, Y.-R. Tang, J Clin Lab Anal. 2020, 34, e23197.

23. M. H. C. Gurgel, C. M. M. Ponte, R. Fontes, I. V. Rocha, L. A. A. Batista, T. C. S. Sousa, R. M. Montenegro Junior, Arch. Endocrinol. Metab. 2020, 64, 362-368.

24. N. Reix, C. Massart, M. d'Herbomez, F. Gasser, B. Heurtault, A. Agin, Clin Biochem. 2013, 46, 1305-1308.

DOI:10.1016/j.clinbiochem.2013.04.015e 


\section{Povzetek}

Za oceno delovanja ščitnice in klinično odločanje je ključnega pomena uporaba ustreznih referenčnih intervalov za tirotropin $(\mathrm{TSH})$, prosti tiroksin $\left(\mathrm{pT}_{4}\right)$ in prosti trijodtironin $\left(\mathrm{pT}_{3}\right)$. Priporočljivo je, da vsak laboratorij pripravi lastne referenčne intervale. Za prvo slovensko postavitev referenčnih intervalov za ščitnične hormone smo retrospektivno zbrali veliko skupino 1722 zdravih posameznikov brez ščitnične bolezni. Analizo hormonov smo izvedli na avtomatiziranem analizatorju Advia Centaur XP Immunoassay System (Siemens Healthineers). Proizvajalčevi referenčni intervali za TSH so bili $0,55-4,78 \mathrm{mIU} / \mathrm{L}$, za $\mathrm{pT}_{4} 11,5-22,7 \mathrm{pmol} / \mathrm{L}$ in $\mathrm{za} \mathrm{pT}_{3} 3,5-6,5 \mathrm{pmol} / \mathrm{L}$. Za statistično obdelavo podatkov smo uporabili neparametrično metodo. Naši laboratorijski referenčni intervali za TSH, $\mathrm{pT}_{4}$ in $\mathrm{pT}_{3}$ so bili v glavnem ožji kot tisti, ki jih je predlagal proizvajalec. Mediana vrednost in razpon sta bila za TSH 1,98 (0,59-4,23) $\mathrm{mIU} / \mathrm{L}, \mathrm{za} \mathrm{pT}_{4} 14,5$ $(11,3-18,8) \mathrm{pmol} / \mathrm{L}$ in za $\mathrm{pT}_{3} 4,82(3,79-6,05) \mathrm{pmol} / \mathrm{L}$. Najverjetnejši vzrok za takšen rezultat raziskave je bila vključenost velikega števila zdravih posameznikov brez ščitnične bolezni.

Except when otherwise noted, articles in this journal are published under the terms and conditions of the Creative Commons Attribution 4.0 International License 